\title{
Is Excellence Inclusive? The Benefits of Fostering Black Female College Athletes' Sense of Belonging
}

\author{
Akilah R. Carter-Francique, Ph.D. \\ Prairie View A\&M University
}

"I've learned that people will forget what you said, people will forget what you did, but people will never forget how you made them feel” - Dr. Maya Angelou (2012)

\section{Introduction}

Two-thousand seventeen demarked a significant year for Black female professionals in intercollegiate athletics. First, University of South Carolina (USC) women's basketball team won the National Collegiate Athletic Association's (NCAA) basketball tournament. Led by head coach Dawn Staley, USC beat Mississippi State University 67-55 (Associated Press, 2017). Staley is a former Atlantic Coast Conference (ACC) female athlete of the year from the University of Virginia (1991, 1992), a three-time member of the United States Olympic team (1996 - Atlanta, Georgia, 2000 - Sydney, Australia, 2004 - Athens, Greece), and a former Women's National Basketball Association (WNBA) player (Charlotte Sting, Houston Comets). A highly accomplished player, USC's win makes Staley the second Black coach to win an NCAA women's basketball championship title, 18 years after Purdue University's Carolyn Peck (Walker, 2017). Second, in October of the same year Carla Williams became the first Black female athletic director at the University of Virginia (Daves, 2017). Similar to Staley, Williams is a former All-Southeastern Conference (SEC) basketball guard and coach at the University of Georgia - Athens (UGA) as well as a seasoned administrator in intercollegiate athletics at the university (Florida State University, Vanderbilt University, UGA), conference (SEC), and national organization (NCAA) levels. Despite Staley's and Williams' historic achievements, statistics reveal that Black females are underrepresented in intercollegiate athletics as administrators and coaches (Lapchick, Marfatia, Bloom, \& Sylervain, 2017).

Between Staley and Williams' successes was the release of The Institute for Diversity and Ethics in Sport's (TIDES) 2016 Racial and Gender Report Card for college sport. As the director of TIDES, Dr. Richard Lapchick and his colleagues at the University of Central Florida awarded intercollegiate athletics, i.e., College Sports, a $\mathrm{C}+$ grade for racial and gender hiring practices (Lapchick et al., 2017). The rationale for the grade is in part due to the representation of Black females in professional positions. For example, the report illuminated that Black females represent 3.1 percent of college head coaches in women's sports compared to 32.3 percent White females (and 0.7 percent Latina, 0.6 percent Asian Pacific Islander, 0.1 percent Native American/Pacific Islander, 0.5 percent two or more races, 0.8 percent Non-resident alien, and 0.6 percent Other). The report notes that of all of the Racial and Gender Report Cards (e.g., National Basketball Association [NBA], National Football League [NFL], Major League Soccer [MLS], and Women's 
Basketball Association [WNBA]), College Sport received the lowest combined grade (for specific details on the grading scale see TIDES [n.d.]) (Lapchick et al., 2017). While there is further evidence to support his awarded grade, Dr. Lapchick specifically noted in the college sport report:

There are far more career prospects in college sport than professional sport. There are more jobs. Thus, it is even more important for us to create expanded opportunities in college sport for women and people of color. We need new ways to open the hiring process for women and people of color. (Lapchick et al., 2017, p. 3)

Following the release of the report, the Chicago Tribune exclaimed, "College sports needs more women - and women of color - in coaching ranks" (Ryan, 2017). The article reflected the TIDES results and illuminated Lapchick's suggestion for the NCAA and its respective member institutions to institute efforts beyond a "presidential pledge" to include policies (e.g., Eddie Robinson Rule, Judy Sweet rule), best practices, and an urge of consequential sanctions to promote greater access for female coaches and coaches of color (Ryan, 2017). I, too, believe this is an important and necessary effort, but it is also important and necessary to promote the development of females and coaches of color while in college, prior to entering the job market. Hence, the purpose of this research note is to urge intercollegiate athletic departments and their administrators to foster a sense of belonging amongst Black female college athletes to aid in their felt membership as a college athlete and support their development as viable employment candidates in college sport.

\section{Black Female College Athletes as the Other}

Some may wonder why there is an emphasis on increasing the representation of Black females to include administrators, coaches, and athletes in intercollegiate athletics. Black females in American society are "Othered", meaning their race, sex, and social class categorizations historically place them on the margins of society and render them without representation (invisible) and without a voice (silenced) (Collins, 1993, 2000; hooks, 1981, 2000; King, 1988). This societal marginalization is constant and permeates social (i.e., education, politics, religion) and cultural (i.e., music, sport) institutions through systemic processes. Therefore, with sport as a microcosm of society, it also reflects similar and in some cases more pronounced issues and challenges for Black females (Bruening, 2005; Cahn, 1994; Sloan-Green, Oglesby, Alexander, \& Franke, 1981; Smith, 1992, 2000; Vertinsky \& Captain, 1998). The response to said marginalization is the promotion of diversity and inclusionary practices that support groups that were and are excluded from dominant spaces and positions of power. But in the quest for diversity and inclusion in sport, Black females have yet to reap the benefits and parity as their Black male and White female counterparts (Bruening, 2005; Smith, 1992, 2000).

For example, Title IX of the Education Amendments of 1972 (Title IX) states, "No person in the United States shall, on the basis of sex, be excluded from participation in, be denied the benefits of, or be subjected to discrimination under any education program or activity receiving Federal financial assistance" (United States Department of Justice, 2015). This amendment suggests equal participation, equal benefits, and equal treatment are guaranteed to all sexes; however, the implementation of this legislative amendment results in a falsehood for Black 
females (and other women of color) because they live at the intersection of a marginalized sex and a marginalized race (Abney \& Richey, 1991, 1992; Carter-Francique \& Flowers, 2013; CarterFrancique \& Richardson, 2016; Mathewson, 1995; Olson, 1990; Rhoden, 2012; Ryan, 2017). More directly, in the 46th year of Title IX, White women remain the prime beneficiary of its legislation.

For instance, Mathewson's (1995) Black Women, Gender, Equity and the Function at the Junction explicates how Title IX's quest for gender equity conflicts with racial justice efforts and results in the notion of "single axis" and "essentialists dynamics" in favor of White females. Using intercollegiate athletics as an example, Black female college athlete representation at the Division I (DI), Division II (DII), and Division III (DIII) levels combined equals 9.3 percent compared to 72.6 percent White females (and 5.1 percent Latinas, 2.4 percent Asian/Pacific Islanders, and 0.4 percent Native American females, 4.1 percent two or more races, 6.2 percent Non-resident aliens, and 3.5 percent other). Of this percentage, Black females culminate the highest representational percentage for women of color with 12.6 percent at the DI level (compared to 66.0 percent White females, 4.8 percent Latinas, 2.3 percent Asian/Pacific Islanders, 0.4 percent Native American/Alaskan Native, 4.1 percent two or more races, 6.2 percent Non-resident Aliens, and 3.5 percent Other). Based on their representation, the greatest concentration of Black females is in the sports of basketball (45\%) and track and field (23.9\%) with limited representation in sports like lacrosse, soccer, swimming, and volleyball (Carter-Francique \& Flowers, 2013; McDowell \& Carter-Francique, 2016; Rhoden, 2012).

So, yes, Black females have reaped Title IX benefits (i.e., increased participation, increase receipt of college athletic scholarships), but they have not experienced those benefits to the same degree and/or range as White females. This representational reality as participants, and as administrators and coaches, gives rise to the nature of Black female college athletes' life experiences. In addition, Black female participant representation coupled with their coach and administrator representation give rise to the limited peers and personnel to support and guide their matriculation efforts, especially in Historically White Institution of Higher Education (HWIHE) that lack a critical mass of Black female students, faculty, and staff.

\section{College Life Experiences and Academic Engagement}

In 1997, Sellers, Kuperminc, and Damas examined the life experiences of 154 Black female college athletes from 39 HWIHE utilizing survey data from the 1987 American Institutes for Research (AIR) and stated this group was "performing adequately academically, integrating socially within the university, perceiving some social advantage as the result of being athletes, and are fairly satisfied with their life" (p. 699). Given the date of their quantitative research, Sellers and colleagues' (1997) assertion of Black female college athletes was informative but troublesome by only examining quantitative measures from another data source. Thus, they did not capture the qualitative nature of the Black female college athletes' life and academic experiences. It is probable that the inclusion of qualitative exploration of the Black female college athletes' "fairly satisfied with life" results would have yielded some experiential challenges based on their "Othered" status (Carter-Francique, 2017).

Furthermore, centering Black female college athletes, Sellers and colleagues (1997) may have found that Black females' historical and contemporary experiences in HWIHEs are demarked 
by treatment marginalization to the point that they are navigating intercollegiate athletics and higher education individually with no mentors nor guiding models (Bruening, Armstrong, \& Pastore, 2005; Carter, 2008; Carter \& Hawkins, 2011; Corbett \& Johnson, 2000; Newhall \& Buzuvis, 2008; Smith, 2000; Withycombe, 2011). Much of the current research about Black female college athletes employs intersectionality theories and illuminates treatment discrimination experiences that (a) make it necessary for them to develop coping strategies (Carter \& Hawkins, 2011); (b) mar their athletic development (Withycombe, 2011); and (c) hinder their self-concept through negative interactions with coaches and administrators and media representations (Bruening, Armstrong, \& Pastore, 2005; Foster, 2003).

Noting the current research, there are a breadth of studies about Black female college athletes' psychosocial and sociocultural experiences, but a dearth of studies exist on how marginalized treatment affects their lone academic engagements (see Cooper, Cooper, \& Baker, 2016). Research on Black female college athletes' academic engagements is often coupled with their Black male counterparts as a collective racial group. The results of the collective research reveal: (a) they are underprepared socially and academically; (b) systemic racism, sexism, and athletic status contribute to negative stereotypes of intellectual inferiority (e.g., dumb jocks) by faculty, staff, students and the greater society; (c) they are "Othered", alienated, and isolated; and, (d) they are victim to false or inaccurate assumptions about their perspectives on academic success and educational desires (Carter-Francique, Hart, \& Steward, 2013; Eitzen \& Purdy, 1986; Sellers, 1992; Stone, Harrison, \& Mottley, 2012; Young \& Sowa, 1992). Despite these collective findings, much of the research exploring the academic engagement of Black college athletes is focused on Black male college athletes due to their historical and contemporary low graduation rates, particularly in revenue-producing sports of football and men's basketball (Beamon, 2008; Beamon \& Bell, 2006; Benson, 2000; Bimper, Harrison, \& Clark, 2013; Donnor, 2005; Edwards, 1983, 1984, 2000; Hawkins, 2013; Hyatt, 2003; Martin, Harrison, Stone \& Lawrence, 2010; Singer, 2008).

Still, what is known about Black female college athletes' academic engagements specifically is that their graduation rates are on the rise. Using the Federal Graduation Rate (FGR), 67 percent of DI Black female college athletes are graduating compared to 49 percent of their nonathlete counterparts (Brutlag-Hosick \& Durham, 2017). Using the same rates, 55 percent of Black males, 78 percent of White females, and 66 percent of White male college athletes are graduating comparatively (Brutlag-Hosick \& Durham, 2017). Therefore, Black female college athletes are exhibiting comparable academic success to White males and are only 11 points below White females. Yet, despite their five-point graduation rate rise from 2013 (Brutlag-Hosick, 2013), this success has not translated into increased hiring rates for Black females in intercollegiate athletics. While the correlation of the relationship between graduation rates and hiring rates is unclear, there is a belief that the best candidates for coaching and administrative positions will come from the vestiges of current and future Black female college athletes.

Nonetheless, Black female college athletes psychosocial and sociocultural challenges within HWIHE can affect their academic endeavors (e.g., joining academic organizations, obtaining internships, participating in career networks) and willingness to pursue post-college careers. Due to these challenges in HWIHE intercollegiate athletics and the greater society, it is my belief that fostering a sense of belonging for Black female college athletes can promote a sense 
of community through membership and an appreciation that their needs of social support and development will be met through said membership (McMillian \& Chavis, 1986). To date, the research endeavors, statistical reports, and known lived experiences reflect an agreement that, despite increases in participation and achievements, Black female college athletes reside within the ever changing "matrix of domination" (e.g., hegemonic, structural, disciplinary, interpersonal; Collins, 2000, pp. 227-229). Thus, there is a need for empowerment efforts that encourage Black female college athletes to understand how they are impacted by race, sex, and social class intersectionality, and there is a need for advocacy efforts that support and influence decisions and policies for marginalized persons within institutional systems like college sport.

\section{Supporting Black Female College Athletes}

My efforts to advocate for Black female college athletes began with my own existence as a Black female college athlete at the University of Houston in the late 1990's. That lived experience eventually fueled my doctoral dissertation and my research agenda to redress the historical and contemporary inequities of my sisters at HWIHEs. Reading research from pioneering scholars like Sloan-Green and colleagues (1981), Abney and Richey (1991, 1992), Vertinsky and Captain (1998), Abney (1999), Smith (1992, 2000), Cahn (1994), Corbett and Johnson (2000), and Bruening (2005), I was able to identify my shared experiences and elucidate the richness and value of being a Black female college athlete. In addition, I began to recognize that while this pioneering research was produced, there were no specific actions, formal policies, or programs that emerged or that the NCAA instituted to promote inclusionary practices to aid in their matriculation and holistic development as an "Other".

\section{An Ethic of Care}

As a former college athlete, I maintain a deep regard for the development and well-being of Black female college athletes; and, in 2013, I wrote An Ethic of Care: Black Female College Athletes and Development. The goal of this manuscript was twofold: to describe the benefits of athletic departments' fostering Black female college athletes' social development and to suggest a culturally relevant framework to aid in creating programs that center Black female college athletes. In my review of the contemporary experiences, I, too, found similar and, in some cases, additional aspects of marginalization (e.g., religious affiliation, sexual orientation), alienation, and isolation that were exposed in the 1980's and 1990's.

Consequently, I argued for the need of developmental programs rooted in Afrocentric Feminist Epistemology for Black female college athletes. This framework maintains four necessary dimensions consisting of (a) concrete experience as a criterion of meaning, (b) the use of dialogue in assessing knowledge claims, (c) the ethic of caring, and (d) the ethic of personal accountability (Collins, 2000); however, of the four dimensions, the ethic of care was found to be the most applicable in HWIHEs. The ethic of care's applicability was based on its three components (i.e., personal uniqueness, appropriateness of emotions in dialogues, capacity for empathy; Collins, 2000) that supported Black female college athletes' developmental needs as well as their academic and social engagements (Carter-Francique, 2013). Additionally, the ethic of care was and is applicable in the intercollegiate athletics setting because of, again, the lack of a critical mass of Black female administrators, coaches, faculty, and staff to serve as mentors and role 
models such to pass on knowledge and wisdom, facilitate meaningful dialogues, and nurture Black female college athletes' ability to be accountable.

Notwithstanding the proposed benefits of this framework, I feel its declaration fell on deaf ears as only one program, entitled Sista to Sista, emerged out of that work. The Sista to Sista program included the ethic of care dimension and was guided by the Afrocentric Feminist Epistemology. In full disclosure, the program was created and facilitated by my colleague Dr. Deniece Dortch and myself and was then instituted at Texas A\&M University during our tenure. A number of valuable issues were addressed through the program workshops that resulted in beneficial aspects for Black female college athletes such as research studies that added to the aforementioned scholarship on Black female college athletes (Carter-Francique, 2013; CarterFrancique, Dortch, \& Carter-Phiri, 2017) and research that supported the development of other scholarly endeavors (Dortch \& Patel, 2017). Even with the beneficial aspects, I contend that my desire to institute an inclusionary program to redress systemic oppressions (e.g., racism, sexism, classism) at an individual level cannot be resolved with an individual level endeavor. Arguably, HWIHEs and their respective athletic departments' culture must change to meet the needs of its contemporary diversified student population because these groups were not considered during its founding nor the establishment of its institutional structuring, mission, and traditions (Duderstadt, 2003).

\section{Diversity and Inclusion in Higher Education and Intercollegiate Athletics}

The concept of diversity in higher education emerged from the vestiges of affirmative action legislation and the pronounced Regents of the University of California $v$ Bakke 1978 case decision (Gurin, Dey, Hurtado \& Gurin, 2002). Since that case, others emerged but not all agreed with the notion and benefits of higher education diversification (see Gurin et al., 2002; Hopwood v University of Texas, 1996; Johnson v. Board of Regents of the University of Georgia, 2000). Still, diversity in its conception would slowly and astutely become a necessary mainstay in the facilitation of American higher education. Diversity in education is defined as "... the sum of the ways that people are both alike and different;" and thus, "the dimensions of diversity include race, ethnicity, gender, sexual orientation, language, culture, religion, mental and physical ability, class, and immigration status" (National Education Association, n.d.). Employing this definition, the Association of American Colleges and Universities (AAC\&U) suggest diversity, “. . . should be talked about as 'inclusive excellence,' for only when a campus is truly inclusive can it make a claim to excellence" (Haring-Smith, n.d.).

The association level endorsement of diversity has trickled down to member colleges and universities and has led many campuses to create diversity units/departments, diversity officers, and policies and programs within and throughout the campuses to include athletic departments. Athletic departments, like many departments, are guided by their respective national governing associations like the NCAA that also promote diversity and inclusive excellence for their professional staff and students. For example, the NCAA's (n.d.a) inclusion statement presents a diverse and inclusive culture as, "dimensions of including, but not limited to, age, race, sex, class, national origin, creed, educational background, religion, gender identity, disability, gender expression, geographical location, income, marital status, parental status, sexual orientation and work experiences". This buttresses their framework for inclusive excellence demarked by the 
integration of "... diversity and inclusion values into each functional area - from hiring practices to classroom instruction - with the realization that the only way to ensure quality and sustainable efforts is through a comprehensive and multilayered approach" (NCAA - Membership Spotlight, n.d.b). Thus, the dual articulation for inclusive excellence is significant, as the messaging permeates throughout institutions to include its processes and practices.

These statements suggest diversity and inclusion are the desired goals of higher educational institutions employing inclusive excellence as a guiding principle to (a) "uncover inequities," (b) "identify effective educational practices," and (c) "build such practices organically for sustained institutional change" (AAC\&U, n.d.). While institutions of higher education recognize the value of diversity and inclusion, Black faculty (female and male combined) represent only three percent across all institutions of higher education (U. S. Department of Education - National Center for Education Statistics, 2017). Acknowledging how the three percent representation materializes within HWIHEs is important. Likewise, the NCAA recognizes the value of diversity and inclusion; however, as Lapchick and colleagues's (2017) Racial and Gender Report Card for college sport indicates, the efforts towards hiring do not reflect this sentiment. Therefore, the result of inclusive excellence is deteriorating to the point that professional Black women in the college sports ranks are of prime concern. So, understanding the role diversity and inclusion is said to play within institutions of higher education and intercollegiate athletics, it is troublesome to consider how the current hiring rates and the possible effect the lack of administrative and coaching representation has and will have on Black female college athletes' interests in professional college sports careers.

Advocating for Black female athletes and professionals in intercollegiate athletics requires practical actionable strategies that incorporate diversity assessments, organizational learning, professional development, and transformative practices (Halualani, Haiker, \& Lancaster, 2010; Hurtado, Alvarez, Guillermo-Wann, Cuellar, \& Arellano, 2012; Hurtado \& Halualani, 2014). The incorporation of these strategies empowers faculty and staff to be agents of change to promote inclusive excellence that benefits higher education, its employees, and its students. But it should also be noted, "The concept of individual sense of belonging can be thought of as an essential component of achieving inclusive excellence because of its connection with student success and redefining higher education as a diverse community of students, scholars, and staff' (Hurtado, 2012, p. x).

\section{Sense of Belonging in Intercollegiate Athletics}

The purpose of this research note, again, is to encourage intercollegiate athletic administrators, staff, and coaches to foster a sense of belonging for Black female college athletes. Historically and contemporarily, Black females are "Othered," and endure experiences of alienation and isolation in intercollegiate athletics and higher education environments. Therefore, promoting a sense of belonging can aid institutions of higher education, athletic departments, and their personnel to redress social injustices and cultivate an environment of inclusive excellence for Black female college athletes. The concept of a sense of belonging acknowledges "marginalization, alienation, and isolation" as conceptual opposites; and it would behoove intercollegiate athletics to provide social support for its diversified populations to include "students who are marginalized in college contexts such as women, racial and ethnic minorities, low-income students, first-generation students, and gay students" (Strayhorn, 2012, p. 17). 


\section{Definition, Core Elements, and Benefits of a Sense of Belonging}

The concept of a sense of belonging is connected to the conceptual theory for a sense of community (McMillan \& Chavis, 1986). Accordingly, a sense of community is defined as "a feeling that members have of belonging, a feeling that members matter to one another and to the group, and a shared faith that members' needs will be met through their commitment to be together" (McMillan \& Chavis, 1986, p. 9). Acknowledging this definition, the elements of membership, influence, integration and fulfillment of needs, and shared emotional connection are deemed significant in cultivating the feelings and needs of community. Within the element of membership, a sense of belonging comprises one of the five attributes required to aid in membership development.

Dr. Terrell Strayhorn (2012) has built on the sense of belonging and used it to explore a number of marginalized groups like Latino students, gay students, first-year college students, students of color, Black male students, and graduate students. Through his work, he has come to define a sense of belonging as "students' perceived social support on campus, a feeling or sensation of connectedness, the experience of mattering or feeling cared about, accepted, respected, valued by, and important to the group (e.g., campus community) or others on campus (e.g., faculty, peers)" (Strayhorn, 2012, p. 17). The respective definition surmises that the sense of belonging is a psychological concept and a building block that attends to basic human needs (see Maslow's [1943] Hierarchy of Needs). Therefore, recognizing the felt marginalization of Black female college athletes along with their social support needs (Carter-Francique, Hart, \& Cheeks, 2015; Carter-Francique, Hart, \& Steward, 2013) and fostering a sense of belonging may also prove beneficial to their overall development and well-being at HWIHE.

Embracing Strayhorn's (2012) sense of belonging theoretical interpretation, research, and conceptual model is helpful to articulate why belongingness matters in intercollegiate athletics environment. More directly, his conceptual interpretation employs seven core elements to aid practitioners to ensure that marginalized students' sense of belonging is achieved. The seven core elements suggest that a sense of belonging: (a) is a basic human need; (b) is a fundamental motive, sufficient to drive human behavior; (c) takes on heightened importance (i.e., in a certain context, at certain times); (d) is related to, and seemingly a consequence of mattering; (e) affects college students and intersects with social identities; (f) engenders other positive outcomes; and, (g) must be satisfied on a continual basis and likely change as circumstances, conditions, and contexts change (Strayhorn, 2012, pp. 18-23).

Addressing the core elements promotes beneficial assurance that students' psychological well-being and social functioning will be considered and that they will exhibit positive emotions like calm, happiness, and joy to promote academic achievement, academic persistence, and academic retention. The benefits of fostering a sense of belonging for marginalized populations in intercollegiate athletics are no different than marginalized students in the general institutional population. Thus, like Strayhorn posits, it is my desire that Black female college athletes "feel respected, valued, accepted, cared for, and that they matter in the classroom, at college, or in their chosen career path" (The Ohio State University - University Center for the Advancement of Teaching, 2018). 


\section{Sense of Belonging in College Sport}

Arguably, some people may assume life as a college athlete equates an automatic sense of belonging. The fraternity of college athletics began officially in 1906 with the NCAA founding. Today there are approximately 500,000 college athletes dispersed across three divisions, and 1,123 universities and colleges. Yet there is ample literature to illustrate the role that race and racism, sex and sexism, class and classism, and sexual orientation and heterosexism plays to marginalize students within intercollegiate athletic environments; thus, requiring the implementation of inclusion education and services. The NCAA Inclusion office response to research and experiences is a host of inclusion resources like statistical databases, symposiums/forums/conventions, committees and tasks forces, reports and workbooks, and awards and honors (NCAA, n.d.c).

Concerning marginalized students, the NCAA's Inclusion's Best Practices (2014) publication provides ten best practices for diversity dimensions based on race, sex (specifically women), sexual orientation, disability (i.e., learning, physical), and international status. The NCAA (2014) states:

Lessons from past struggles, disappointments, and triumphs have taught us that the most effective diversity and inclusion efforts: - Have a clear mission and enthusiastic support from executive leadership. • Are well resourced and connected to the broader campus infrastructure. - Involve students, coaches, staff, administrators, faculty and — where appropriate — parents and community. • Include evaluation and assessment mechanisms that allow program coordinators to measure progress and make adjustments along the way. $\bullet$ Become embedded in the systems and practices that are integral to the institutional culture. (p. 19)

This statement is noteworthy and evidence that fostering a sense of belonging for all students, not just on behalf of Black female college athletes, is understood. But if this effort was truly embraced by all member institutions, then why the drop in racial and gender diversity endeavors? Again, Lapchick and colleagues' (2017) report reveals college sport's C+ grade. This grade suggests that not all member institutional efforts to promote inclusive excellence, specifically for women of color (e.g., Black women) in the professional ranks, are effective.

Career experiences and barriers of Black females in college sport. Black female coaches and administrators like Staley and Williams are products of NCAA member institutions that were demarked by a history of alienation and isolation of Black female college athletes. While Staley and Williams represent "success" stories, it is a wonder as to how many other Black female college athletes could transition to work as professionals in intercollegiate athletics if their respective member institutions adopted inclusive excellence practices encompassing a sense of belonging. I make this statement as extant research on the NCAA and its member institutions'

racial and gender composition connote the need for a diverse organizational culture, particularly with its hiring practices and representative administrators and coaches (Anderson, 1993; Cunningham \& Sagas, 2004; Fink, Pastore, \& Reimer, 2001). Based on research and the 2017 college sports report conducted by TIDES, the NCAA remains a transitional organization. I echo this characterization of the NCAA as a transitional organization as defined by having a mission 
that espouses a desire for diversity and a culture that maintains "White and male norms" with "prejudice and discrimination lessened, but continue[s]" to "seek accommodation to and comfort/tolerance for minorities" and "reif[ies] particular group identities" (DeSensi, 1994, p. 70). Further proof that the NCAA is a transitional organization is their treatment and concern for professional women of color (e.g., Black females).

In 2015, the NCAA released the Perceived Barriers for Ethnic Minority Females in Collegiate Athletics Careers report. The report was commissioned by two of their own professional inclusion committees, the Minorities Opportunities and Interests Committee and the Committee for Women's Athletics. The purpose of their investigation was:

To collect empirical evidence outlining the factors that influence ethnic minority women's careers, including: (1) obstacles (perceived or real) potential applicants may face when contemplating a career in athletics; and (2) obstacles institutions may face in recruiting and retaining ethnic minority women in coaching and administrative positions. (NCAA, 2015, p. 1)

Utilizing a 20-minute online survey, a total of 529 women of color (representing only $10 \%$ of the total population) responded across three NCAA divisions (i.e., DI, DII, DIII) and revealed four significant findings regarding the females' (a) current level of job satisfaction, (b) why numbers are so low, (c) hiring perceptions as deterrents, and (d) desire to remain in career in intercollegiate athletics.

First, the data revealed that 80 percent of the female participants were satisfied with their job and, if given the opportunity, they would choose a career in intercollegiate athletics. Then, 66 percent of the females stated they would encourage female college athletes of color to also pursue a career in intercollegiate athletics. However, less than 41 percent were satisfied with the intercollegiate athletics environment and their subsequent treatment in that environment. Second, the females indicated that their representational numbers were so low due to the lack of organizational awareness and its career networks, commitments to their family, and the lack of information about- and access to- available jobs in intercollegiate athletics. Third, the females' perceptions of the hiring processes served as a deterrent due to known experiential discrimination and hiring patterns that privilege White and male persons over "Others". Fourth, the females revealed that despite the host of access barriers and negative felt treatment experiences, they would like to advance their careers in intercollegiate athletics as an administrator at their respective institutions or the conference level or coach at the DI level.

Based on the findings, the NCAA (2015) prescribed nine recommendation efforts the women should engage in to redress the aforementioned findings and lived experiences. They include:

(a) professional development opportunities; (b) exposure to professional organizations; (c) networking opportunities with other athletics leadership; (d) networking opportunities with search firms; (e) information about career opportunities in athletics; (f) information to help supervisors and search firms become more aware in hiring; (g) information about internships, grants or 
scholarships for ethnic minority women; (h) online discussion forums with ethnic minority women; and, (i) urging institutions to re-examine hiring practices to ensure diversity and inclusion. (p. 3)

Ultimately, the recommendations place the onus on the females to identify ways (e.g., networking, organizational membership) to access intercollegiate athletics and assimilate to the NCAA culture through informational workshops and developmental opportunities to circumvent possible discriminatory treatment and advance.

The findings of the NCAA (2015) report are not surprising because it affirms the shared career experiences and barriers women of color (e.g., Black females) incur in society (Bell, 1990; Crenshaw, 1989; Holmes \& Frye, 2016; Jones \& Shorter-Gooden, 2003; Mays, Coleman, \& Jackson, 1996; Scarborough, 1989) and in sport (Abney, 2007; Abney \& Richey, 1991; Borland \& Bruening, 2010; Carter-Francique \& Olushola, 2016; McDowell, 2008; McDowell \& CarterFrancique, 2017; McDowell \& Cunningham, 2009; Price, Dunlap, \& Eller, 2017). For example, prior to the NCAA's report, Abney and Richey (1991) examined the state of Black female administrators and coaches and found that they experienced access and treatment discrimination based on their race and sex, political and social ideologies rooted in hegemonic traditions, and a lack of representation and/or persons with the cultural competence to be sensitive to marginalized persons. Consequently, they concluded that Black females experience a set of barriers in HWIHEs such as inadequate salary, lack of support groups, and lack of cultural and social outlets in the community.

In 2017, approximately 26 years after Abney and Richey (1991), McDowell and I (2017) examined the experiences of Black female athletic directors (ADs). As members of the collective women of color, we found similar negative and marginalized experiential realities expressed by Abney and Richey (1991) and the NCAA Perceived Barriers for Ethnic Minority Females in Collegiate Athletics Careers (2015) report. We employed Crenshaw's (1991) intersectionality framework, which illuminated how historical stereotypes and systemic oppressions manifested contemporarily at the structural, representational, and political levels. Thus, we found that race and sex ideologies along with political and social traditions implicitly and explicitly influenced the thoughts and behaviors of the people Black female ADs interacted with. More specifically, the research illuminated that the "Othered" nature of Black women's identity operated simultaneously and affected their perceived personality (e.g., aggressive, bossy), assumed access (e.g., affirmative action hires), and treatment based on presumed occupational roles (e.g., administrative assistant) and career advancement potential (e.g., low competence in advanced position) in intercollegiate athletics.

The amalgamation of research and overall findings on women of color suggest that the NCAA and the culture of intercollegiate athletics must truly change to embrace diversity and inclusion. Still, I am appreciative of scholars that challenge and guide the NCAA's diversity and inclusion efforts through research and reports, presentations, conferences, summits, and organizations. Nevertheless, the NCAA's efforts to embrace diversity and inclusion and exhibit inclusive excellence are necessary, but to do so they must adopt a multicultural mentality. Therefore, to move from transitional to multicultural, the NCAA must commit to major change strategies that comprise "continuous (re)education and growth of individuals and organization", 
"reward multicultural work", "multicultural norms and leadership at all levels", "coalition formation", "revise policies and structures", and the willingness to "combat external social oppression" (DeSensi, 1994, p. 72). In turn, the efforts will reflect an organizational culture in which "prejudice and discrimination [are] constantly confronted publicly and negatively sanctioned", "alternative norms are publicized and embraced", "White, male, and Eurocentric symbols are changed", and there is a "synthesis of individual characteristics, group identities, and transcendent community" (DeSensi, 1994, p. 70). While embracing such an organizational identity would demonstrate a commitment to inclusive excellence, the NCAA as a member-led association made up of over 1,000 universities and colleges must ultimately be the ones to commit to the aforementioned major change strategies. To do so, the member institutions must respect the increased diversification of its athletes and acknowledge possible alternative pathways to achieve inclusive excellence.

\section{Fostering a Sense of Belonging for Black Female College Athletes}

Black female college athletes represent a small proportion of the college athlete demographic, yet they are making academic inroads and exhibiting athletic excellence while simultaneously experiencing:

.. racial discrimination, "womanism" (the act of women hindering the success of other women), class oppression, inadequate or biased counseling at the precollegiate and collegiate levels, and a lack of minority women as role models and mentors [that] limit the initial visibility of African American [Black] women in coaching and administrative positions. (Abney \& Richey, 1991, p. 19)

Interestingly, this historical description of Black female college athletes' experiences is still relevant. Therefore, the combination of academic persistence, athletic excellence, and continued marginalization based on their race, gender, social class and other identities make these women prime students worthy of an environment that fosters a sense of belonging for their overall success and well-being. Using Strayhorn's (2012) seven core elements for the sense of belonging in this final section, I will attempt to illuminate the need and ways to foster this organizational concept and its corresponding model.

First, a sense of belonging is a basic human need. The fulfillment of belonging allows "knowledge, understanding, and self-actualization" to occur such that students can thrive in the university and college environment (Strayhorn, 2012, p.18). This first element is important for Black female college athletes because, as previously explicated, they experience such a level of "Otherness" in society that it permeates into their sporting endeavors. Therefore, myths, stereotypes, and preconceived notions influence their self-definitions and affect their daily interactions and relationships with peers, coaches, staff, and faculty. Departments should offer ways to (re)educate all persons whom will interact with Black female college athletes to ensure they gain an understanding of their historical and contemporary experiences, opportunities, and barriers; as personnel, they will have a new level of cultural competence to provide social support and felt belongingness. 
Second, a sense of belonging is a fundamental motive, sufficient to drive human behavior. The desire to belong influences a student's positive and negative life efforts. For example, membership into an academic organization, sorority, or athletic team require some level of assimilation which may influence and compromise a student's ethics, morals, and identity. Black females are documented as making a historical impact in intercollegiate athletics through their championship endeavors at the NCAA level to the Olympic Games at the international level. Despite these achievements, Black females are placed on the margins of intercollegiate athletics and face challenges as participants, coaches, and athletic administrators with no culturally relevant programs or services, and limited policies speak to their specific educational needs and career development. Departments should engage support service departments (e.g., counseling, career) and organizations (e.g., Black student association) to aid Black female college athletes' development of communication skills and coping mechanisms.

Third, a sense of belonging takes on a heightened importance (i.e., in a certain context, at certain times). The way a student feels can vary and change depending on the context, the time, and the dynamics of the situation. It is noted through the presented research and literature that Black female college athletes' felt sense of belonging is contextual and non-monolithic. Thus, depending on the university or college (i.e., geographic location, power five conference school), the classroom (e.g., business, engineering, health and kinesiology, psychology) or athletic space (e.g., basketball, golf, gymnastics, track and field), interactions as a visible college athlete or a student, and year in school (e.g., first year, fourth year) can influence the positive or negative nature of their treatment and value at a HWIHE. Therefore, a department's ability to identify advocates for Black female college athletes in the respective spaces and places have the ability to (re)educate and offer social support through providing a safe space for development.

Fourth, a sense of belonging is related to, and seemingly a consequence of mattering. A student's ability to discern if they feel valued, respected, and/or accepted for who they are is important. Arguably, some college athletes, including Black female athletes, only feel they matter because of their athletic status and team affiliation. The affirmed value of their athleticism by various groups (i.e., family, peers, institutional personnel, fans) can create identity challenges often favoring one identity over another (e.g., athlete over student, athlete over race, athlete over gender). Departments should engage personnel and promote programming that acknowledges the challenges in intercollegiate athletics and that fosters the ability of college athletes to normalize the negotiation of identities from the student, to the athlete, to racialized and gendered "Other".

Fifth, a sense of belonging affects college students and intersects with social identities. Considering the "consequence of mattering" and Black female athletes' identity negotiations, it can be understood as to how they may feel valued and respected while on the court, field, or track and simultaneously alienated and excluded in the classroom or isolated from the general student body during the championship season. Therefore, departmental personnel should be mindful of how Black female college athletes may be treated outside of athletic spaces and identify programs and services, faculty and staff, and even non-athletic peers that can support bridge-building (rather than barrier creation) and provide social support for all of their identities. For instance, asking Black female college athletes about their interests to include and go beyond their athletic participation demonstrates a willingness and desire to learn about and acknowledge all their identities. 
Sixth, a sense of belonging engenders other positive outcomes. When a student feels valued, cared for, and supported, they are more likely to be actively engaged and motivated to achieve. As a result of student prosocial behaviors, they exhibit happiness and have a greater sense of well-being, whereas the absence of these feelings can promote negative behaviors such as anxiety, depression, and thoughts of suicide. Departments should develop ways to recognize Black female college athletes' value through awards, student leadership appointments (e.g., team captain, Student Athletic Advisory Council), and encouragement to participate in activities, groups, and programs in and outside of intercollegiate athletics that can aid in their sense of belonging.

Seventh, a sense of belonging must be satisfied on a continual basis and likely change as circumstances, conditions, and contexts change. Students' ability to forge authentic relationships with key personnel like academic advisers, faculty in their respective majors, or student organization members is helpful throughout their tenure. Departments should encourage institutional faculty, staff, coaches, and administrators to facilitate opportunities for Black female college athletes to forge relationships (i.e., peer and career mentors, role models) upon arrival to the institution and work to support the continual engagement and development each year up to and beyond graduation.

\section{Conclusion}

I began this research note wanting to urge intercollegiate athletic departments and their administrators to foster a sense of belonging for Black female college athletes. It is my hope that I dutifully explicated and provided insight on the need to adopt and implement this concept. Black female college athletes' experiential realities are diverse, just as their ability to matriculate is diverse. Hence, many Black female college athletes, to include me, have navigated their way through university and college athletic and academic programs with great success. However, it is my belief that the nature of that navigation can be enhanced through inclusive excellence rooted in the sense of belonging elements. Through a commitment to major changes in diversity and inclusion policies and practices, the NCAA and its member institutions can support Black female college athletes, encourage their identity development, and nurture their academic engagement and career aspirations. HWIHEs emboldening such an organizational philosophy would be ideal, and would potentially inspire Black females to apply for professional positions in intercollegiate athletics at all types and levels of institutions as coaches, administrators, and faculty. Intercollegiate athletic departments' and their respective athletic directors' willingness to foster a sense of belonging demonstrates their dedication to cultivate an organizational culture that Black females, and other women and people of color, see and are made to feel is a viable career pathway and an inclusive organization. 


\section{References}

Abney, R. (1999). African American women in sport. Journal of Physical Education, Recreation \& Dance, 70(4), 35-38.

Abney, R. (2007). African American women in intercollegiate coaching and athletic administration: Unequal access. In D. Brooks \& R. Althouse (Eds.), Diversity and social justice in college sport: Sport management and the student athlete (pp. 51-75). Morgantown, VA: Fitness Information Technology, Inc.

Abney, R. \& Richey, D. (1991). Barriers encountered by Black female athletic administrators and coaches. Journal of Physical Education, Recreation \& Dance, 62(6), 19-21.

Abney, R. \& Richey, D. (1992). Opportunities for minority women in sport - The impact of Title IX. Journal of Physical Education, Recreation \& Dance, 63(3), 56-59.

Anderson, D. (1993). Cultural diversity on campus: A look at intercollegiate football coaches. Journal of Sport and Social Issues, 17(1), 61-66.

Angelou, M. (2012). A conversation with Dr. Maya Angelou. In L. McIntosh \& L. Taylor, Beautifully Said Magazine. Retrieved from http://beautifullysmagazine.com/201207feature-of-the-month-3/

Associated Press (2017, April 3). South Caroline defeats Mississippi State to win NCAA women's basketball title. Fox News: Sports. Retrieved from http://www.foxnews.com/sports/2017/04/03/south-carolina-defeats-mississippi-state-towin-ncaa-womens-basketball-title.html

Association of American Colleges \& Universities [AAC\&U] (n.d.). Making excellence inclusive. $A A C \& U$. Retrieved from https://www.aacu.org/making-excellence-inclusive 
Beamon, K. K. (2008). “Used goods”: Former African American college student-athletes' perception of exploitation by division I universities. The Journal of Negro Education, $77(4), 352-364$.

Beamon, K., \& Bell, P. A. (2006). Academics versus athletics: An examination of the effects of background and socialization on African American male student athletes. The Social Science Journal, 43(3), 393-403.

Bell, E. L. (1990). The bicultural life experience of career-oriented black women. Journal of Organizational Behavior, 11(6), 459-477.

Benson, K. F. (2000). Constructing academic inadequacy: African American athletes'stories of schooling. The Journal of Higher Education, 71(2), 223-246.

Bimper, A. Y., Harrison, L., \& Clark, L. (2013). Diamonds in the rough: Examining a case of successful Black male student athletes in college sport. Journal of Black Psychology, 39(2), 107-130.

Borland, J. F., \& Bruening, J. E. (2010). Navigating barriers: A qualitative examination of the under-representation of Black females as head coaches in collegiate basketball. Sport Management Review, 13(4), 407-420.

Bruening, J. (2005). Gender and racial analysis in sport: Are all the women White and all the Blacks men? Quest, 57, 340-359.

Bruening, J. E., Armstrong, K. L., \& Pastore, D. L. (2005). Listening to the voices: The experiences of African American female student athletes. Research Quarterly for Exercise and Sport, 76(1), 82-100.

Brutlag-Hosick, M. (2013). Division I student-athletes show progress in graduation success rate. NCAA: News. Retrieved from 
www.google.com/amp/s/amp.ncaa.com/amp/news/ncaa/article/2013-10-24/division-istudent-athletes-show-progress-graduation-success-rate

Brutlag-Hosick, M. \& Durham, M. (2017 November 8). DI African-American student-athletes graduate at record rates: Success for minorities helps push overall Graduation Success Rates to $87 \%$. NCAA: News. Retrieved from www.ncaa.org/about/resources/mediacenter/news/di-african-american-student-athletes-graduate-record-rates

Cahn, S. (1994). Coming on strong: Gender and sexuality in the twentieth-century women's sport. New York, NY: Free Press.

Carter, A. R. (2008). Negotiating identities: Examining African American female collegiate athlete experiences in predominantly White institutions (Doctoral dissertation, University of Georgia). Athens, GA: University of Georgia.

Carter, A. R., \& Hawkins, B. J. (2011). Coping strategies among African American female collegiate athletes' in the predominantly White institution. In K. Hylton, A. Pilkington, P. Warmington, \& S. Housse (Eds.), Atlantic crossings: International dialogues on critical race theory (pp. 61-92). Birmingham, UK: University of Birmingham Higher Education Academic Network.

Carter-Francique, A. R. (2013). Black female collegiate athlete experiences in a culturally relevant leadership program. The National Journal of Urban Education \& Practice, 6(2), 87-106.

Carter-Francique, A. R. (2017). Theoretical considerations in the examination of African American Girls and women in sport. In A. Ratna \& S. F. Samie (Eds.), Race, Gender, and Sport: The Politics of Ethnic 'Other' Girls and Women (pp. 63-84). United Kingdom: Routledge. 
Carter-Francique, A. R., Dortch, D., \& Carter-Phiri, K. (2017). Black female college athletes’ perception of power in sport and society. Journal for the Study of Sports and Athletes in Education, 11(1), 18-45.

Carter-Francique, A. R. \& Flowers, C. (2013). Intersections of race, ethnicity, and gender in sport. In E. Roper (Ed.), Gender relations in sport (pp. 73-94). The Netherlands Rotterdam: Sense Publishers.

Carter-Francique, A. R., Hart, A., \& Cheeks, G. (2015). Examining the value of social capital and social support for Black student-athletes' academic success. Journal of African American Studies, 19(2), 157-177.

Carter-Francique, A., Hart, A., \& Steward, A. (2013). Black college athletes’ perceptions of academic success and the role of social support. Journal of Intercollegiate Sport, 6(2), 231-246.

Carter-Francique, A. R., \& Olushola, J. (2016). Women coaches of color. In N. M. Lavoi (Ed.), Women in Sports Coaching (pp. 81-94). New York, NY: Routledge.

Carter-Francique, A. R., \& Richardson, F. M. (2016). Controlling media, controlling access: The role of sport media on Black women's sport participation. Race, Gender \& Class, 23(1/2), 7.

Collins, P. H. (1993). Toward a new vision: Race, class, and gender as categories of analysis and connection. Race, Sex \& Class, 25-45.

Collins, P. H. (2000). Black feminist thought: Knowledge, consciousness, and the politics of empowerment, $2^{\text {nd }}$ edition. New York: NY: Routledge. 
Cooper, J. N., Cooper, J. E., \& Baker, A. R. (2016). An anti-deficit perspective on Black female scholar-athletes' achievement experiences at a Division I historically White institution (HWI). Journal for the Study of Sports and Athletes in Education, 10(2), 109-131.

Corbett, D., \& Johnson, W. (2000). The African-American female in collegiate sport: Sexism and racism. In D. Brooks and R. Althouse (Eds.), Racism in college athletics: The African American athlete's experience, 2 (pp. 199-225). Morgantown, VA: Fitness Information Technology, Inc.

Crenshaw, K. (1989). Demarginalizing the intersection of race and sex: A Black feminist critique of antidiscrimination doctrine, feminist theory and antiracist politics. University of Chicago Legal Forum., 139-167.

Crenshaw, K. (1991). Mapping the margins: Intersectionality, identity politics, and violence against women of color. Stanford Law Review, 43, 1241-1299.

Cunningham, G. B., \& Sagas, M. (2004). Racial differences in occupational turnover intent among NCAA Division IA assistant football coaches. Sociology of Sport Journal, 21(1), 84-92.

Daves, J. (2017, October 22). Carla Williams names Virginia director of athletics. UVAToday. Retrieved from https://news.virginia.edu/content/carla-williams-named-virginiadirector-athletics

DeSensi, J. T. (1994). Multiculturalism as an issue in sport management. Journal of Sport Management, 8(1), 63-74.

Donnor, J. K. (2005). Towards an interest-convergence in the education of African-American football student athletes in major college sports. Race Ethnicity and Education, 8(1), 4567. 
Dortch, D., \& Patel, C. (2017). Black undergraduate women and their sense of belonging in STEM at predominantly White institutions. NASPA Journal About Women in Higher Education, 10(2), 202-215.

Duderstadt, J. J. (2003). Intercollegiate athletics and the American university: A university president's perspective. Ann Arbor, MI: University of Michigan Press.

Edwards, H. (1983). The Exploitation of Black Athletes. AGB Reports, 25(6), 37-46.

Edwards, H. (1984). The Black “dumb jock”: An American sports tragedy. College Board Review, 131, 8-13.

Edwards, H. (2000). Crisis of Black athletes on the eve of the 21st century. Society, 37(3), 9-13.

Eitzen, D. S., \& Purdy, D. A. (1986). The academic preparation and achievement of Black and White collegiate athletes. Journal of Sport and Social Issues, 10(1), 15-29.

Fink, J. S., Pastore, D. L., \& Riemer, H. A. (2001). Do differences make a difference? Managing diversity in Division IA intercollegiate athletics. Journal of Sport Management, 15(1), 10-50.

Foster, K. M. (2003). Panopticonics: The control and surveillance of Black female athletes in a collegiate athletic program. Anthropology \& Education Quarterly, 34(3), 300-323.

Gurin, P., Dey, E., Hurtado, S., \& Gurin, G. (2002). Diversity and higher education: Theory and impact on educational outcomes. Harvard Educational Review, 72(3), 330-367.

Halualani, R. T., Haiker, H., \& Lancaster, C. (2010). Mapping diversity efforts as inquiry. Journal of Higher Education Policy and Management, 32(2), 127-136.

Haring-Smith, T. (n.d.). Broadening our definition of diversity. Association of American Colleges \& Universities: Liberal Education. Retrieved from 
Journal of Higher Education Athletics \& Innovation Volume 1, Issue 3 https://www.aacu.org/publications-research/periodicals/broadening-our-definitiondiversity

Hawkins, B. (2013). The new plantation: Black athletes, college sports, and predominantly White NCAA institutions. New York, NY: Palgrave Macmillan.

Holmes, K. \& Frye, J. (2016, August 23). African American women in the U.S. Economy. Center for American Progress. Retrieved from https://www.americanprogress.org/issues/women/reports/2016/08/23/142815/african -american-women-in-the-u-s-economy/

hooks, b. (1981). Ain't I a woman: Black women and feminism. Boston, MA: South End. hooks, b. (2000). Feminist theory: From margin to center. London, UK: Pluto Press. Hurtado, S. (2012). Foreward. In T. L. Strayhorn, College students'sense of belonging. A key to educational success for all students (pp. ix-x). New York, NY: Routledge.

Hurtado, S., Alvarez, C. L., Guillermo-Wann, C., Cuellar, M., \& Arellano, L. (2012). A model for diverse learning environments. In J. C. Smart and M. B. Paulsen (Eds.), Higher education: Handbook of theory and research, Volume 27 (pp. 41-122). New York, NY: Springer.

Hurtado, S., \& Halualani, R. (2014). Diversity assessment, accountability, and action: Going beyond the numbers. Diversity \& Democracy, 17(4), 8-11.

Hyatt, R. (2003). Barriers to persistence among African American intercollegiate athletes: A literature review of non-cognitive variables. College Student Journal, 37(2), 260-276. Jones, M. C., \& Shorter-Gooden, K. (2003). Shifting: The double lives of Black women in America. New York, NY: Harper Collins. 
King, D. K. (1988). Multiple jeopardy, multiple consciousness: The context of a Black feminist ideology. Signs: Journal of Women in Culture and Society, 14(1), 42-72.

Lapchick, R., Marfatia, S., Bloom, A. \& Sylervain, S. (2017, April 6). The 2016 racial and gender report card: College sport. The Institute for Diversity and Ethics in Sport. Retrieved from http://nebula.wsimg.com/38d2d0480373afd027ca38308220711f?AccessKeyld=DAC3A5 6D8FB782449D2A\&disposition=0\&alloworigin=1

Martin, B. E., Harrison, C. K., Stone, J., \& Lawrence, S. M. (2010). Athletic voices and academic victories: African American male student-athlete experiences in the PacTen. Journal of Sport and Social Issues, 34(2), 131-153.

Maslow, A.H. (1943). A theory of human motivation. Psychological Review, 50(4), 370-396.

Mathewson, A. D. (1995). Black women, gender equity and the function at the junction. Marq. Sports LJ, 6(2), 239-266.

Mays, V. M., Coleman, L. M., \& Jackson, J. S. (1996). Perceived race-based discrimination, employment status, and job stress in a national sample of Black women: Implications for health outcomes. Journal of Occupational Health Psychology, 1(3), 319-329.

McDowell, J. (2008). Head black woman in charge: An investigation of Black female athletic directors' negotiation of their gender, race, and class identities. Unpublished doctoral dissertation, Texas A\&M University, College Station, Texas.

McDowell, J., \& Carter-Francique, A. (2016). Experiences of female athletes of color. In E. J. Staurowsky (Ed.), Women and sport: From liberation to celebration (pp. 95-116). Champaign, IL: Human Kinetics. 
McDowell, J., \& Carter-Francique, A. (2017). An intersectional analysis of the workplace experiences of African American female athletic directors. Sex Roles, 77(5), 1-16.

McDowell, J., \& Cunningham, G. B. (2009). Personal, social, and organizational factors that influence Black female athletic administrators' identity negotiation. Quest, 61(2), 202222.

McMillan, D. W., \& Chavis, D. M. (1986). Sense of community: A definition and theory. Journal of Community Psychology, 14(January), 6-23.

National Collegiate Athletic Association [NCAA] (n.d.a). Inclusion statement. NCAA: Inclusion. Retrieved from http://www.ncaa.org/about/resources/inclusion/ncaa-inclusionstatement

National Collegiate Athletic Association [NCAA] (n.d.b). Membership spotlight. NCAA: Inclusion. Retrieved from http://www.ncaa.org/about/resources/inclusion/membership-spotlight

National Collegiate Athletic Association [NCAA] (n.d.c). Office of inclusion. NCAA: Resources. Retrieved from http://www.ncaa.org/about/resources/inclusion

National Collegiate Athletic Association [NCAA] (2014). Inclusion's best practices. NCAA: Inclusion. Retrieved from http://www.ncaa.org/sites/default/files/InclusionsBestPractices.pdf

National Collegiate Athletic Association [NCAA]. (2015). NCAA Perceived barriers for ethnic minority females in collegiate athletics careers. NCAA Publications. Retrieved from http://www.ncaapublications.com/productdownloads/BarriersReport2015.pdf

National Education Association [NEA] (n.d.). Diversity toolkit introduction. NEA: Teaching Strategies. Retrieved from http://www.nea.org/tools/diversity-toolkit-introduction.html 
Newhall, K. E., \& Buzuvis, E. E. (2008). (e)Racing Jennifer Harris sexuality and race, law and discourse in Harris v. Portland. Journal of Sport \& Social Issues, 32(4), 345-368.

Olson, W. (1990). Beyond Title IX: An agenda for women and sports in the 1990's._Yale JL \& Feminism, 3, 105-151.

Price, T., Dunlap, R., \& Eller, J. (2017). An exploration of Black women's intersectionality in athletic administration. Journal of Issues in Intercollegiate Athletics, 10, 57-77.

Rhoden, W. C. (2012, June 10). Black and White women far from equal under Title IX. The New York Times: Sports of The Times. Retrieved from http://www.nytimes.com/2012/06/11/sports/title-ix-has-not-given-black-femaleathletes-equal-opportunity.html

Ryan, S. (2017, April 17). College sports needs more women - and women of color - in coaching ranks. The Chicago Tribune: Sports. Retrieved from http://www.chicagotribune.com/sports/columnists/ct-womens-college-coaching-diversityryan-spt-0419-20170417-column.html

Scarborough, C. (1989). Conceptualizing Black women's employment experiences. The Yale Law Journal, 98(7), 1457-1478.

Sellers, R. M. (1992). Racial differences in the predictors for academic achievement of studentathletes in Division I revenue producing sports. Sociology of Sport Journal, 9(1), 48-59.

Sellers, R. M., Kuperminc, G. P., \& Damas, A. (1997). The college life experiences of African American women athletes. American Journal of Community Psychology, 25(5), 699-720.

Singer, J. N. (2008). Benefits and detriments of African American male athletes' participation in a big-time college football program. International Review for the Sociology of Sport, 43(4), 399-408. 
Sloan-Green, T., Oglesby, C., Alexander, A., \& Franke, N. (1981). Black women in sport. Reston, VA: American Alliance of Health and Physical Education Recreation and Dance (AAHPERD) Publications.

Smith, Y. R. (1992). Women of color in society and sport. Quest, 44(2), 228-250.

Smith, Y. (2000). Sociocultural influences of African American elite sportswomen. In D. Brooks and R. Althouse (Eds.), Racism in college athletics: The African American athlete experience, $2^{\text {nd }}$ ed., (pp. 173-197). Morgantown, VA: Fitness Information Technology, Inc.

Strayhorn, T. L. (2012). College students' sense of belonging: A key to educational success for all students. New York, NY: Routledge.

Stone, J., Harrison, C. K., \& Mottley, J. (2012). "Don't call me a student-athlete”: The effect of identity priming on stereotype threat for academically engaged African American college athletes. Basic and Applied Social Psychology, 34(2), 99-106.

The Institute for Diversity and Ethics in Sport [TIDES] (n.d.). Reports. Retrieved from http://www.tidesport.org/reports.html

The Ohio State University - University Center for the Advancement of Teaching (2018). Sense of belonging in the classroom. The Ohio State University: UCAT-Shaping a Positive Learning Environment. Retrieved from https://ucat.osu.edu/bookshelf/teachingtopics/shaping-a-positive-learning-environment/sense-of-belonging-in-the-collegeclassroom/

United States Department of Education, National Center for Education Statistics (2017). The Condition of Education 2017 (NCES 2017-144), Characteristics of Postsecondary Faculty. Retrieved from https://nces.ed.gov/fastfacts/display.asp?id=61 
United States Department of Justice (2015). Title IX of the Education Amendments of 1972, 20

U.S.C. Retrieved from http://www.justice.gov/crt/overview-title-ix-educationamendments-1972-20-usc-1681-et-seq

Vertinsky, P. \& Captain, G. (1998). More myth than history: American culture and representations of the Black female's athletic ability. Journal of Sport History, 25(3), $532-561$

Walker, R. (2017, April 3). Carolyn Peck elated for Dawn Staley as second Black coach to win women's basketball title: 'Now that there's a one and a two, there'll be a three. And the excitement that gives me a thrilling.' The Undefeated: NCAAW. Retrieved from https://theundefeated.com/features/carolyn-peck-elated-for-dawn-staley-as-second-blackcoach-to-win-womens-basketball-title/

Withycombe, J. L. (2011). Intersecting selves: African American female athletes' experiences of sport. Sociology of Sport Journal, 28(4), 478-493.

Young, B. D., \& Sowa, C. J. (1992). Predictors of academic success for Black student athletes. Journal of College Student Development, 33(4), 318-324. 